\title{
Sobre a recepção de $O$ Antigo Regime e a Revolução pela historiografia da Revolução Francesa: da publicação da obra ao contexto do Bicentenário de 1789
}

\section{The Reception of Tocqueville's The Old Regime and the Revolution by the Historiography of the French Revolution: from its Publication to the Bicentenary of 1789}

\author{
José Miguel Nanni Soares ${ }^{1}$ \\ Universidade de São Paulo (Brasil)
}

Recibido: 24-03-19

Aprobado: 07-05-19

\section{Resumo}

O presente artigo pretende oferecer uma visão geral -embora sumária- da recepção de $O$ Antigo Regime e a Revolução pela historiografia da Revolução Francesa, desde sua publicação até o contexto da celebração do Bicentenário de 1789.

Procurou-se demonstrar como, a despeito de relevantes opiniões elogiosas e favoráveis da parte de eminentes historiadores e críticos literários, a célebre obra tocquevilliana enfrentou sérios desafios editoriais e ideológicos entre o momento de sua publicação, em junho de 1856, e o primeiro centenário de sua publicação.

A partir da mudança dos ventos representada pelo pós-Guerra (anos cinquenta do século $\mathrm{XX}$ ) e, em grande medida, devido às importantes contribuições do eminente historiador republicano e socialista Georges Lefebvre, a obra histórica de Tocqueville passou a atrair uma crescente consideração dos historiadores

\footnotetext{
1 (miguelnanni@usp.br) Professor de História Moderna da USP (Universidade de São Paulo Brazil), autor de uma tradução (com estudo introdutório e notas) de $O$ Antigo Regime e a Revolução, publicada em 2016. Autor também de Joseph de Maistre: intérprete da Revolução e da Modernidade (tese de doutoramento defendida na Universidade de São Paulo, em 2014) e de uma tradução (com introdução e notas) para o português das Reflections on the Revolution in France, de Edmund Burke, em 2014.
} 
profissionais e do grande público, a ponto de tornar-se um autor central na historiografia e no debate político contemporâneo a partir do Bicentenário da Revolução de 1789 .

Palavras-chave: Tocqueville, Historiografia, Revolução Francesa, Liberalismo, Conservatismo.

\section{Abstract}

The purpose of this paper is to offer an overview -although summaryof The Old Regime and the Revolution by the historiography of the French Revolution, from its publication to the context of the Bicentennial celebration (1789-1989).

Among other aspects, it was demonstrated how, in spite of relevant and favorable opinions from eminent historians and literary critics, the famous Tocqueville work faced serious editorial and ideological challenges in the period between June 1856 and the first centenary of its appearance.

In the wake of the postwar changes of the 1950s and, to a large extent, due to the important contributions of the eminent republican and socialist historian Georges Lefebvre, Tocqueville's historical work began to attract a growing consideration of academic historians and the general public, becoming a pivotal author in both historiography and contemporary political debate during and after the celebration of the Bicentenary of the Revolution of 1789 .

Key-words: Tocqueville, Historiography, French Revolution, Liberalism, Conservatism.

Inicio o texto lembrando que o material historiográfico disponível sobre a renomada obra de Tocqueville é quase interminável, razão pela qual nos limitaremos aqui a apresentar, em linhas sumárias e gerais, uma pequena peça de um gigantesco mosaico que é a recepção do livro pela historiografia da Revolução Francesa entre o momento de sua publicação, em 1856, e as produções que vieram à luz no contexto do Bicentenário de 1789 .

Comecemos lembrando o ano de publicação do livro, em junho de 1856. Com duas edições num único semestre, a obra suscitou especial interesse de um grupo de intelectuais e políticos liberais que, no contexto pós-golpe de Estado de 1851, fazia oposição seja ao cesarismo de Napoleão III seja ao socialismo emergente (com suas reivindicações de sufrágio universal). Como destacou o scholar Richard Herr, para esses liberais de oposição, a tese principal de $O$ Antigo Regime e a Revolução, a saber, a da continuidade da 
centralização administrativa, caiu como uma luva para sua orientação política. Vinculada pela historiografia da Revolução Francesa -tanto à direita como à esquerda do espectro político- à Revolução de 1789 ou ao Primeiro Império, a denúncia tocquevilliana da centralização administrativa proporcionava-lhes uma justificativa ao mesmo tempo política e psicológica para os sucessivos fracassos das duas gerações de políticos liberais pós-1789 no estabelecimento e consolidação de um regime representativo e liberal na França.

Assim, para aqueles liberais pós-1848, O Antigo Regime e a Revolução demonstrava que tal fracasso devia-se mais ao peso do passado do que aos erros dos seus antepassados, de 1789 em diante. Exemplo disso encontramos na carta que o professor de política comparada do Collège de France, Edouard Laboulaye, remeteu a Tocqueville:

Tudo o que você escreveu sobre a centralização atraiu minha atenção, ainda mais por ser familiar do monstro. C'est l'infâme qu'il faut écraser [é o infame que é preciso esmagar], se desejarmos ter liberdade em nosso pobre país ${ }^{2}$.

Naquele mesmo ano, o liberal Charles de Rémusat, que, a exemplo de Tocqueville, viu-se forçosamente afastado da política após o golpe de dois de dezembro de 1851, destacou a originalidade e a qualidade historiográfica da obra:

Foi penetrando, com uma curiosidade inteligente e meticulosa, nos detalhes da vida da velha França que o senhor de Tocqueville soube tornar suas pesquisas interessantes, suas observações, originais, e suas conclusões, sólidas... Ele dispensou tudo o que os outros haviam descoberto, escrito e pensado. Ele foi direto às fontes, consultando as peças e não os livros, inquerindo os fatos e não as reflexões alheias. O que ele nos dá é o resultado da observação direta.

O mesmo Rémusat, um pouco mais adiante, sublinha a condenação do passado absolutista francês por Tocqueville, que era também a de muitos liberais de sua geração:

Ao penetrar nas profundezas das coisas..., resgatou a realidade da aparência e, julgando em última instância, pronunciou uma irrevogável sentença de condenação [do Antigo Regime] ${ }^{3}$.

${ }^{2}$ Carta reproduzida en Richard Herr, Tocqueville and the Old Regime, Princeton University Press, 1962, p. 112-113. Ademais, importa destacar o quanto aqueles liberais, na feliz expressão de Herr, pareciam não ter se dado conta de que o antídoto oferecido por Tocqueville (o enraizamento do cesarismo na própria história nacional francesa) era tão ou mais mortífero do que o veneno que ele se propunha a combater.

${ }^{3}$ Charles de Rémusat, "L'Ancien Régime et la Révolution, de M. de Tocqueville”, Revue des Deux Mondes, $2^{\mathrm{e}}$ série, IV (1856), p. 655 e 656.

Araucaria. Revista Iberoamericana de Filosofia, Politica, Humanidades y Relaciones Internacionales, año $21, \mathrm{n}^{\circ} 42$. Segundo semestre de 2019. Pp. 319-349. ISSN 1575-6823 e-ISSN 2340-2199 doi: 10.12795/araucaria.2019.i42.13 
No entanto, a recepção imediata à obra não ficou circunscrita aos elogios daquela corrente liberal de oposição. Entre os principais contendores da interpretação tocquevilliana, destacaram-se os políticos e intelectuais que, alinhados com o bonapartismo e defensores de sua tradição, não aceitavam a condenação da centralização administrativa por Tocqueville. Tendo no crítico literário Sainte-Beuve seu principal representante, os membros deste grupo destacavam o que consideravam ser os exageros e as imprecisões históricas presentes em $O$ Antigo Regime e a Revolução. Assim, enquanto o político Adolphe Forcade de la Roquette, amparado na obra histórica do liberal Adolphe Thiers (cujas implicações fatalistas ou deterministas Tocqueville abominava, pois, a seu ver, suprimiam ou escamoteavam o âmbito da liberdade humana na narração histórica), apontava as imprecisões factuais de Tocqueville como historiador, especialmente por associar os intendentes da antiga monarquia aos prefeitos do Consulado e do Império, Sainte-Beuve, reiterando e aprofundando as acusações, dizia que Tocqueville fora levado ao erro seja pelo método dedutivo (que, na célebre fórmula do autor de Causeries du Lundi, teria levado Tocqueville a pensar antes de começar a aprender, o que explicaria o caráter teleológico de sua produção histórica ${ }^{4}$ ), seja pela ausência de um maior rigor em sua pesquisa.

Em seu artigo, Sainte-Beuve fez questão de apontar os benefícios da centralização monárquica tão criticada por Tocqueville, dentre eles a a aliança entre a realeza e a burguesia contra a nobreza feudal - união esta responsável pelo gradual avanço da igualdade civil (conceito este que, extraído dos historiadores liberais da Restauração, fora adaptado pelo próprio Tocqueville no prefácio do primeiro volume de Da Democracia na América, de 1835, e no ensaio L'État Social et Politique de la France avant et depuis 1789, de 1836) -, a formação da nacionalidade e a manutenção da integridade territorial francesa nos quadros das constantes guerras entre os séculos XV e XVII (da Guerra dos Cem Anos à Guerra dos Trinta Anos), sobre as quais, como é sabido, O Antigo Regime e a Revolução praticamente silenciara ${ }^{5}$.

\footnotetext{
4 "Esta é uma daquelas afirmações retrospectivas que implicam que se tem em mãos todos os elementos do problema, todos os fios e as fontes da história. Admiro as chamadas mentes filosóficas por terem, em tal assunto, tais certezas. Que tentem, então, levar a cabo tais afirmações afiadas sobre os fatos presentes e em curso de desenvolvimento, e receberão desmentidos a cada passo. Não há nada tão brutal quanto um fato."Cf. Charles Augustin Sainte-Beuve, Causeries du Lundi, t. XV Paris, Garnier Frères, 1857, p. 98.

${ }^{5}$ Vale a pena reproduzir um trecho da crítica de Sainte-Beuve à condenação tocquevilliana ao absolutismo monárquico: "Em seu pavor pela centralização, o autor chega a ignorar as grandes conquistas da igualdade devidas a Richelieu e a Luís XIV.... Não amaldiçoemos aqueles a quem devemos os primórdios da igualdade perante a lei, o primeiro esboço da ordem moderna que nos libertou....Mergulhado nos arquivos de uma única província, ele não tinha suficientemente presente no espírito o quadro inteiro daquele Antigo Regime cuja representação ele exagerava e cujos últimos benefícios, ao mesmo tempo, ignorava". Cf. Charles Augustin Sainte-Beuve, Causeries du Lundi, t. XV Paris, Garnier Frères, 1857, p. 97.
} 
A recepção da obra tocquevilliana por Sainte-Beuve é de grande valia para os estudiosos que se debruçam sobre o tema da historiografia da Revolução Francesa do século XIX. Pois o mesmo Sainte-Beuve que censurou Tocqueville por haver descoberto "mil novas razões para odiar o Antigo Regime" sem, no entanto, acrescentar "razões novas para amar a Revolução", é o que elogiou o contrarrevolucionário saboiano Joseph de Maistre e suas obras, entre elas o panfleto pós-termidoriano Considerações sobre a França (1797), onde o processo revolucionário francês é descrito como nada menos do que uma revolução satânica e condenado em bloco pelos seus princípios liberais, que, segundo o autor, remontariam à Reforma religiosa do século XVI e desembocariam na filosofia das Luzes (fruto maduro da razão individualista protestante e responsável por solapar os pilares da civilização, a soberania política e a religião) ${ }^{7}$.

Mais do que as idiossincrasias de Sainte-Beuve, o que nos interessa aqui é destacar a atmosfera cultural e política da França no momento em que Tocqueville publicou seu livro sobre a Revolução. E o clima político subsequente às jornadas revolucionárias de 1848 fora marcado marcado pela reação, por um tênue equilíbrio entre classes que até então tinham colecionado inimizades (os aristocratas legitimistas e a burguesia orleanista), mas que, diante da "ameaça vermelha" representada pelas novas demandas de cunho socialista, decidiram cerrar fileiras em torno do bonapartismo (cuja principal base de apoio social, como denunciou Marx em seu livro de 1852, O Dezoito Brumário, era o campesinato) ${ }^{8}$.

À primeira vista, poderíamos imaginar que esta inflexão conservadora da política francesa de meados do século XIX poderia favorecer a difusão de $O$ Antigo Regime e a Revolução entre o público, mas o fato é que a mensagem liberal da obra não se coadunava facilmente nem com o campo do partido da ordem, nem com o campo democrático (fosse este moderado ou radical), e isto devido ao caráter, por assim dizer, excêntrico ou inusitado do liberalismo contido na obra.

Pois Tocqueville invertera o sentido que os historiadores liberais (tais como François Mignet, Adolphe Thiers, François Guizot, Augustin Thierry) atribuíam à história da França, na medida em que eles absolviam o absolutismo pelo que o mesmo trouxera de favorável ao avanço da igualdade (a ascensão da burguesia, que aparecia escamoteada em suas obras através dos termos “classes médias" e/ou "Terceiro Estado") e, por extensão, da liberdade, com o progressivo rebaixamento da nobreza feudal.

\footnotetext{
${ }^{6}$ Charles Augustin Sainte-Beuve, op. cit., p. 96-97.

${ }^{7}$ Sainte-Beuve, Portraits Littéraires, II vol., Paris: Garnier Frères, 1862, p. 420; Causeries $d u$ Lundi, vol. IV, Paris, Garnier Frères, 1852, p. 192-216.

${ }^{8}$ Vide a sugestiva obra de Antoine Compagnon, que aborda a vaga romântico-conservadora na literatura francesa do século XIX em Les antimodernes, de Joseph de Maistre à Roland Barthes, Paris, Gallimard, 2005.
} 
Outra inversão: se o dilema, para os historiadores liberais da geração anterior, era a desigualdade política ante o progressivo nivelamento social com a marcha da civilização -dilema este que só fora resolvido em 1789 pela via revolucionária-, para Tocqueville, o enigma era o contrário, ou seja, a dissociação entre a ordem civil (uma sociedade crescentemente nivelada em termos materiais e de espírito, mas patologicamente desigual em relação aos direitos, dadas as permanências e reiterações, ainda que marginais, de aspectos feudais, pela ação combinada da monarquia e da prevaricação da nobreza) e a ordem política (cada vez mais homogeneizada e centralizada sob a crescente submissão de todos os súditos ao Estado monárquico).

Como bem observou François Furet ${ }^{9}$ acerca de $O$ Antigo Regime e a Revolução, Tocqueville, em seu estudo de 1856, abandonara a perspectiva liberal que informara o seu opúsculo de 1836, que apresentava o estado social como a fonte principal das mutações históricas, de modo que a Revolução de 1789 seria uma adequação, na esfera jurídico-política, das transformações sociais igualitárias engendradas pela marcha da civilização na longa duração. No livro de 1856, a abordagem (política) da centralização administrativa, responsável pela erosão ou subversão da sociedade francesa feudal (mais propriamente, pelo colapso da aristocracia em termos políticos), precede o exame das transformações sociais, como se Tocqueville tivesse invertido o eixo causal entre as duas esferas. Essa alteração fundamental pode certamente ser atribuída às lições políticas extraídas da experiência recente do nosso autor. $\mathrm{Na}$ percepção dele, o rápido encadeamento de regimes políticos diferenciados não podia mais ser explicado como o reflexo de alterações profundas no estado social, o que não se verificara entre 1830 e 1848 . Tocqueville achou-se então diante do mesmo problema de Guizot e de Marx, que consistia em explicar uma sucessão de revoluções políticas no interior de uma mesma condição social.

Ademais, tanto em $O$ Antigo Regime e a Revolução como nos demais trabalhos de Tocqueville, não se encontra nenhuma simpatia pela burguesia, e, no tocante à aristocracia - apesar de sua linhagem nobre (de pais legitimistas, sua genealogia nobre remontava às invasões normandas da Inglaterra, sendo bisneto, por parte de mãe, de Malesherbes, o renomado nobre de toga que se destacou tanto pela reação ao golpe de Maupeou contra os Parlamentos, entre 1770-1774, como pela defesa de Luís XVI, no julgamento deste último pela Convenção, em janeiro de 1793) e da caracterização um tanto idílica das relações feudais avançadas pela obra de 1856 -, a mesma não deixou de ser responsabilizada pelas decisões que levaram à sua própria ruína. Pois ao permitir que o Estado absolutista taxasse o Terceiro Estado em troca da isenção da participação nas novas talhas régias, a nobreza prevaricou de sua função

\footnotetext{
${ }^{9}$ François Furet, Pensar la Revolución Francesa. Traducción de Arturo R. Firpo, Barcelona, Ediciones Petrel, 1980, primera edicción de 1978.
}

Araucaria. Revista Iberoamericana de Filosofia, Política, Humanidades y Relaciones Internacionales, año $21, \mathrm{n}^{\circ} 42$. Segundo semestre de 2019. Pp. 319-349. ISSN 1575-6823 e-ISSN 2340-2199 doi: 10.12795/araucaria.2019.i42.13 
político-representativa em troca dos privilégios fiscais. Segundo Tocqueville, a partir daquele momento, a nobreza francesa perverteu-se; abandonou o seu devir, que era o de governar os homens localmente -como lograra fazer, apesar do trem civilizatório democrático-nivelador, a aristocracia inglesa, que soube abrir mão dos privilégios fiscais e até moveu uma guerra contra o absolutismo para preservar o seu mando político no nível local-, e marchou gradualmente para o seu nadir, aferrando-se cada vez mais aos inúteis e odiosos privilégios, sendo os fiscais a origem de todos os demais, e também os "mais perigosos" para qualquer classe dominante.

Assim, pela ação combinada do Estado monárquico francês e do egoísmo nobre, a nobreza perdeu o seu princípio definidor (o sangue) e sua função (representação política perante a nação), entregando-se a uma dinâmica social que a separa constantemente do restante da sociedade, pois a única via de reiteração de uma identidade esvaziada de seu verdadeiro espírito político, era o superinvestimento nas diferenças e nos privilégios sociais, aqueles monumentos à vaidade social que o Estado monárquico, em sua sanha fiscal, alimentava incessantemente. Pois ele concedia cada vez mais a nobilitação, mediante a venda de cargos venais, a novos elementos da burguesia ascendente, exasperando assim a vaidade social da antiga nobreza. Esta, por sua vez, desenvolveu uma imaginação social de casta que se transmitiu por todo o tecido social. "Em nenhuma época de nossa história a nobreza era tão facilmente adquirida quanto em 1789, e jamais o burguês e o gentil-homem estiveram tão separados um do outro", advertiu Tocqueville ${ }^{10}$.

Além disso, como também demonstrou Furet, para a historiografia liberal, de Constant e Mme de Stäel a Guizot e Thiers, o misterioso da Revolução, vista ao mesmo tempo como a realização da liberdade e da igualdade, era o Terror, a ditadura do ano II. Em sua narrativa, a burguesia arranca da nobreza a condição de classe privilegiada e derruba o absolutismo, mas, em meio à guerra provocada pela oposição obstinada dos emigrados e de parte considerável do clero, é levada a ceder provisoriamente o terreno às classes populares, pouco inclinadas à liberdade. Tocqueville inverteu essa leitura, tomando por misterioso o breve movimento pela liberdade verificado entre 1787 e o verão de 1789 . Se a liberdade e a igualdade caminharam juntas nas primeiras etapas da Revolução, isto é, da revolta dos notáveis de 1787 à Queda da Bastilha, a partir de outubro de 1789 , a liberdade cede o passo à paixão igualitária, cujas raízes profundas na sociedade francesa remontam à centralização, o que explica a atávica herança despótica do igualitarismo francês.

$\mathrm{Ou}$ seja, a mensagem implícita da obra era que nem a burguesia (majoritariamente orleanista) nem o que restava da aristocracia (fosse ela legitimista ou orleanista) lograram ou souberam atrair a massa rural

\footnotetext{
${ }^{10}$ Alexis de Tocqueville, O Antigo Regime e a Revolução, Livro II, cap. 9.
} 
camponesa - que sancionou o golpe de Estado de Napoleão III- para o esforço de consolidação de instituições livres na França. Como buscará demonstrar no último capítulo do segundo livro de $O$ Antigo Regime e a Revolução, a resistência da cultura despótico-revolucionária se alimentava da impotência recíproca das classes e nos reflexos disso junto ao campesinato, um legado do passado absolutista.

Por fim, e na esteira do que sustentou Roger Boesche ${ }^{11}$, o liberalismo tocquevilliano pode ser descrito como excêntrico (ou, nas palavras do autor, como "estranho") também por que, se por um lado suas obras integravam alguns tópicos da cultura romântica e conservadora então em voga (tais como a defesa da religião e a crítica ao individualismo burguês, ambos presentes na Democracia na América), por outro, ele não vislumbrava saída para a liberdade a não ser na e pela democracia, o que o levou a expressar um liberalismo (político) que, para utilizarmos uma nomenclatura croceana, não era nada "liberista"

Portanto, não devemos ficar surpresos com o fato de a obra histórica de Tocqueville ter, por assim dizer, feito poucos discípulos no campo historiográfico, a despeito das críticas majoritariamente favoráveis que recebeu. Entre 1856 e a Guerra franco-prussiana, o principal trabalho histórico no interior do campo republicano e liberal que, de algum modo, se inspirou em O Antigo Regime e a Revolução foi o La Révolution (1865), de Edgar Quinet. Ali, o conceito tocquevilliano da recaída atávica dos revolucionários franceses no arbítrio ou despotismo do Estado absolutista servira de matéria-prima para Quinet elaborar a sua própria interpretação crítica ao jacobinismo e ao Terror. Como Tocqueville, Quinet acreditava que "o ódio à nobreza enganava os historiadores da burguesia: em nome da luta de classes, eles se esqueciam da liberdade" $"$.

E à direita do espectro político, entre os que abominavam seja a Revolução seja a democracia, as ideias de Edmund Burke, do abade Augustin Barruel e, sobretudo, de J. de Maistre permaneciam hegemônicas. Não por acaso, Tocqueville modulou a composição de $O$ Antigo Regime e a Revolução com vistas a combater tanto o determinismo que ele, no segundo volume de $A$ Democracia na América (1840) ${ }^{14}$, apontou como o principal vício da historiografia em tempos democráticos (e o qual consiste em atribuir os fenômenos apenas a causas gerais e sistêmicas, sufocando ou suprimindo quase que por completo

${ }^{11}$ Roger Boesche, Tocqueville's Road Map, Lanham, Rowman \& Littlefield, 2006, especialmente o capítulo segundo "The Strange Liberalism of Alexis de Tocqueville", onde o autor articula as posições filosóficas e políticas conservadoras de Tocqueville com a cultura filosófica, histórica e literária de sua época.

${ }^{12}$ Benedetto Croce, Liberismo e liberalismo, Milano, Ricciardi, 1988. Primeira edição italiana de 1927.

${ }^{13}$ Steven Laurence Kaplan, Farewell, Revolution: The Historians' Feud: France, 1789/1989, Ithaca, Cornell University Press, 1995, p. 118.

${ }^{14}$ Alexis de Tocqueville, Da Democracia na América, volume II, 1840, I, 20. 
o campo para a iniciativa e a liberdade humanas para o desfecho dos mesmos), como o voluntarismo político implícito na teoria da conspiração.

A respeito desta última, o mérito por sua difusão coube a Edmund Burke e seu célebre panfleto contrarrevolucionário, as Reflexões sobre a Revolução na França (1790), que condenava o fenômeno revolucionário francês, ainda em seus primórdios, como uma conspiração concertada entre os ambiciosos homens de letras e os representantes vulgares do monied interest contra a Coroa, a aristocracia e a Igreja (cujos bens acabaram de ser confiscados), teoria que seria adaptada ao contexto francês da emigração pelo abbé Barruel, cujas Mémoires pour servir à l'histoire du jacobinisme (1797) avançaram a tese mais acolhida pelos reacionários da cultura política francesa da primeira metade do século XIX ${ }^{15}$.

Em seu panfleto, Barruel sustentava a teoria de que a Revolução fora uma violação da história francesa, resultado de uma conspiração - de caráter anárquico e permanente- entre um pequeno grupo de maçons, philosophes e jacobinos contra uma nação satisfeita com sua monarquia ${ }^{16}$.

Todavia, à diferença de Burke e de Barruel, Tocqueville não preservou a monarquia e tampouco a nobreza da responsabilidade pelo advento da Revolução. Não que isto constituísse uma novidade no campo conservador. Antes dele, Sénac de Meilhan, Chateaubriand e o próprio Maistre, cada um à sua maneira, já tinham atribuído o início da Revolução a uma nova "Fronda aristocrática" ${ }^{17}$.

No caso do contrarrevolucionário saboiano, a condenação às principais ordens do reino, a nobreza e o clero às vésperas da Revolução, foi um tópico constantemente reproduzido pelos historiadores favoráveis à Revolução, e dos mais diversos matizes: do liberal Mignet ao democrata Michelet e até mesmo o robespierrista Albert Mathiez, não foram poucos os historiadores favoráveis à Revolução que lançaram mão das obras de Maistre para, com base em seu testemunho "insuspeito", imputar a violência revolucionária à ação cega dos emigrados, cuja causa ameaçava, segundo ele, dividir a França e aniquilar os franceses. Logo, se por um lado Maistre condenava os princípios da Revolução (razão pela qual não estabelecia diferença entre os períodos de 1789 -1791 e 1792-94), o mesmo não ignorava por completo suas conquistas, sendo a principal delas a manutenção da integridade nacional francesa em meio à guerra contra a Europa coligada, apesar da (e também graças à) violência jacobina.

\footnotetext{
${ }^{15}$ Vide Stanley Mellon, Political Uses of History: A Study of Historians in the French Restoration, Stanford University Press, 1958, p. 59-60; Massimo Boffa, "La Rivoluzione e la Controrrivoluzione" [In François Furet, ed.: L'eredità della Rivoluzione Francese, Roma, Laterza, 1989], p. 92.

${ }^{16}$ Amon Hofman, "Opinion, Illusion, and the Illusion of Opinion: Barruel's Theory of Conspiracy" in Eighteenth-century studies, vol. XXVII, 1 (outono de 1993), p. 28.

${ }^{17}$ John McManners, "The Historiography of the French Revolution", in A. Goodwin, The New Cambridge Modern History, vol. VIII: The American and the French Revolution 1763-1793, Cambridge University Press, 1965, p. 621-622.
} 
Portanto, sob o prisma da direita e dado o contexto reacionário e expansionista do Império francês, a interpretação liberal de Tocqueville, que refutava a teoria da conspiração e não condenava os princípios liberais do século XVIII, tinha poucas chances de vicejar.

Ademais, os anos 1848-1880 testemunharam, se me for permitido expressar assim, uma espécie de "Momento Maistre", um boom editorial das obras do contrarrevolucionário saboiano em solo francês, mormente as Considérations sur la France e o Du Pape (1819), influência que extrapolou o mundo histórico e deixou traços visíveis na esfera literária, de Baudelaire ${ }^{18}$ a Stendha ${ }^{19}$, Balzac ${ }^{20}$ e Barbey d'Aurevilly ${ }^{21}$. Para termos uma expressão quantitativa do que afirmamos, enquanto $O$ Antigo Regime e a Revolução contou com 16 edições entre 1856 e 1930, as Considérations tiveram 20, ante 24 edições de Du Pape entre 1848 e 1930.

Paradoxalmente, a obra histórica de Tocqueville exerceria considerável influência naquele livro que se tornaria o principal best-seller da reação francesa à Revolução de 1789 e à democracia após a Comuna de Paris e a traumática derrota militar do país na Guerra franco-prussiana, a saber, As Origens da França Contemporânea (1875-1893), de Hyppolite Taine.

O primeiro volume de As Origens, tendo por subtítulo O Antigo Regime, contém várias alusões e remissões à obra de Tocqueville. Numa delas, Taine escreve: "Pois não é a Revolução, e sim a monarquia que implantou, na França, a centralização". E acrescenta a seguinte nota ao seu texto: "Esta verdade vital foi estabelecida pelo M. de Tocqueville com uma perspicácia superior"22.

A exemplo de Tocqueville, o autor das Origines também lançava o olhar para a Inglaterra aristocrática como um modelo político digno de admiração, e considerava a Revolução como um prolongamento da obra centralizadora monárquica, responsável por eliminar gradualmente a administração local dos notáveis e por difundir o "espírito clássico" (dedutivo e matemático) que se manifestaria no ethos dos revolucionários.

No entanto, ao reduzir o Terror às maquinações dos jacobinos, a uma minoria de fanáticos extraviados que logrou tirar proveito da incapacidade da multidão ("o gorila lúbrico e feroz") para se autogovernar, Taine se aproximava, e isto tanto no espírito como na letra, muito mais de um Maistre do que de Tocqueville, como bem percebeu o historiador Pierre Caron, para

\footnotetext{
${ }^{18}$ Daniel Vouga, Baudelaire et Joseph de Maistre, Paris, J. Corti, 1957.

${ }^{19}$ Stendhal, Le Rouge et le Noir, Paris, Michel Lèvy Frères, 1854, capítulo V.

${ }^{20}$ Honoré de Balzac, Oeuvres, vol I., Scènes de la Vie de Province: Illusions Perdues, Paris: Lévy Frères, 1864, p. 44.

${ }^{21}$ Kevin M. Erwin, "Le Mystique de la Tradition: Barbey Worships at the altar of Joseph de Maistre" [in C. Armenteros e R. Lebrun, eds., Joseph de Maistre and his European Readers: From Friedrich von Gentz to Isaiah Berlin, Leiden, Brill, 2011], pp. 59-74.

${ }^{22}$ Hippolyte Taine, Les Origines de la France Contemporaine. Vol. 1. L'Ancien Régime, 27 edição, Paris, Hachette, 1909, p. 121. Primeira edição de 1875.
} 
quem sua leitura da Revolução poderia muito bem ser (des)qualificada como um "satanismo leigo" 23 .

Curiosamente, e já no âmbito da historiografia universitária da Revolução, tanto Alphonse Aulard como G. Lefebvre avançaram condenações à obra histórica de Taine em termos bastante similares aos que que Sainte-Beuve havia endereçado a Tocqueville, a saber, que o autor das Origines "construiu sua verdade histórica a priori", descartando todos os fatos que não se encaixavam em sua narrativa. De modo que ninguém melhor do que o historiador Charles Seignobos definiu o efeito da obra histórica de Taine, a qual, segundo ele, ao ignorar as circunstâncias em seu vitupério à Revolução, retratava "o quadro de um duelo em que um dos adversários tivesse sido apagado, dando ao outro uma aparência de louco" ${ }^{24}$.

Nos quadros da Comuna de Paris e da derrota militar frente ao exército prussiano, as Origens de Taine serão a principal referência historiográfica e política dos reacionários da conturbada Terceira República francesa. Apesar da crítica que recebera dos nacionalistas reacionários da Ação Francesa, em razão da condenação do espírito clássico, os teóricos daquele movimento dispuseram Taine "entre os primeiros mestres da contrarrevolução"25.

Para termos uma ideia da popularidade desta obra de Taine ${ }^{26}$, descrita por Godechot como "o grande livro da reação francesa" ${ }^{27}$, entre a data da primeira edição e a versão da obra que consultamos (1909), ela contou com nada menos do que vinte e sete edições!

Encontraremos ecos de As Origens da França Contemporânea em Augustin Cochin -que, apesar de discordar do tratamento conferido ao povo, defendeu o seu autor das críticas de Aulard ${ }^{28}$ - e Pierre Gaxotte, que se tornaria o l'enfant terrible da negação violenta à Revolução e, a partir da Revolução de outubro de 1917, na Rússia, ao bolchevismo, através da sua La Révolution Française (1927). A propósito, coube à obra histórica deste antinazista, anticomunista e colaborador da Ação Francesa a façanha de desbancar a de Taine em popularidade entre os reacionários franceses, preservando seu apelo entre os críticos de 1789 até o contexto das celebrações do Bicentenário da Revolução.

\footnotetext{
${ }^{23}$ A citação de P. Caron foi extraída da obra de Alice Gérard, A Revolução Francesa: Mitos $e$ Interpretações. Tradução de Sérgio Joaquim de Almeida, São Paulo, Perspectiva, 1999, p. 71

${ }^{24}$ Georges Lefebvre, Réflexions sur l'histoire, Paris, F. Maspero, 1978, pp. 232-234.

${ }^{25}$ Alice Gérard, A Revolução Francesa: Mitos e Interpretações. Tradução de Sérgio Joaquim de Almeida, São Paulo, Perspectiva, 1999, p. 83.

${ }^{26}$ Lamentamos profundamente não ter reunido condições de oferecer ao leitor uma informação mais precisa a respeito do número das edições de As Origens de Taine - além de O Antigo Regime e a Revolução de Tocqueville, entre outras obras -, pois não logramos acesso à recente e criteriosa catalogação empreendida pela coletânea de Alain de Benoist, intitulada Blibliographie générale des droites françaises, Paris, Dualpha, 2004-5, em 4 volumes.

27 Jacques Godechot, “As grandes correntes da historiografia da Revolução Francesa, de 1789 aos nossos dias". Revista de História, n 80, vol. XXXIX (1969), p. 435.

${ }^{28}$ Augustin Cochin, La Crise de l'histoire révolutionnaire, Paris, 1909.
} 
Além de Taine, Tocqueville deixaria marcas no diplomata e historiador conservador-liberal -embora um conservadorismo bem mais mitigado que o do autor de As Origens-Albert Sorel, autor da volumosa obra L'Europe et la Révolution française (1885-1904). De acordo com McManners, apesar de $O$ Antigo Regime e a Revolução ter "tido uma enorme e continuada influência nos estudos sobre a Revolução", o L'Europe et la Révolution française foi o único livro de história sobre a Revolução diretamente inspirado nele, pelo menos até a voga revisionista de meados da década de 1970 do século XX. A Revolução Francesa, que para muitos teve o aspecto de uma total subversão, e para outros de "uma regeneração do velho mundo europeu", foi vista por A. Sorel como o "natural e necessário resultado da história da Europa". A continuidade com a história francesa, que Tocqueville detectou pela análise da administração e do fracionamento e/ou posse do solo pelo campesinato, Sorel associou com a política externa da antiga monarquia ${ }^{29}$.

Todavia, e talvez ainda mais do que entre os anos 1848-1871, a recepção às ideias e às obras de Tocqueville enfrentou novos obstáculos entre as últimas décadas do século XIX e as primeiras do século seguinte.

Com isto não pretendemos dizer que Tocqueville e $O$ Antigo Regime e a Revolução tivessem caído em total esquecimento. Pelo contrário, a obra fora objeto de leituras elogiosas de eminentes historiadores e críticos literários do final do século, os quais, na contramão do que haviam feito Sainte-Beuve, Forcade de la Roquette e outros, enalteceram as qualidades de Tocqueville como historiador da Revolução.

A começar pelo renomado historiador liberal François Mignet, que em seu Nouveaux Éloges Historiques (1877), destacou o estilo ("puro e amplo") e as ideias de $O$ Antigo Regime e a Revolução, que denotavam as qualidades de seu autor, por ele descrito como um "juiz penetrante", "hábil" e elegante, que jamais abandonou a "elevação moral" em toda a sua produção intelectual ${ }^{30}$.

Em 1895, foi a vez do historiador e crítico literário Gustave Lanson enaltecer a imparcialidade do autor (segundo ele, superior à demonstrada por Guizot) e a profundidade de seu escrito de 1856, que merecia figurar como uma das "duas obras primas filosóficas do nosso século", ao lado de Da Democracia na América ${ }^{31}$. Em seguida, Lanson destacou a originalidade da interpretação histórica de $O$ Antigo Regime e a Revolução. A exemplo dos historiadores liberais, Tocqueville pensa a Revolução como "a consequência, o término de um movimento social e político que se iniciou com as próprias origens da pátria", ao passo que os historiadores legitimistas e democratas interpretavam a Revolução como "uma ruptura violenta com o passado, uma explosão miraculosa e súbita que uns amaldiçoam e outros

\footnotetext{
${ }^{29}$ John McManners, "The Historiography of the French Revolution" [in Elliot H. Goodwin, The New Cambridge Modern History, vol. VIII: The American and the French Revolution 1763-1793, Cambridge University Press, 1965], pp. 637-638.

${ }^{30}$ François-Auguste Mignet, Nouveaux Éloges Historiques, Paris, Didier et Cie, 1877, p. 96.

${ }^{31}$ Gustave Lanson, Histoire de la littérature française, Paris: Hachette, 1895, p. 1002.
} 
bendizem, todos persuadidos de que a França de 1789 e de 1793 não tinha nada em comum com a França de Luís XIV ou de são Luís". Porém, Lanson observou que enquanto os historiadores "orleanistas submetiam sua visão da história aos interesses de um partido", Tocqueville, "mais filósofo, permanecendo estritamente historiador, contenta-se em estabelecer a continuidade do desenvolvimento de nossas instituições e de nossos costumes". Por fim, acrescenta que ele "explica a influência da literatura e da irreligião na Revolução, e o predomínio do sentimento da igualdade sobre a paixão pela liberdade". Tendo assim relatado a destruição das instituições feudais e monárquicas, "Tocqueville planejara mostrar como a nova França fora reconstruída a partir dos destroços da antiga" ${ }^{32}$.

Poucos anos depois, foi a vez do igualmente renomado crítico literário e historiador da literatura, Ferdinand Brunetière, enaltecer a originalidade da interpretação toquevilliana sobre a Revolução de 1789 , bem como sua contribuição para o avanço científico da disciplina histórica:

\begin{abstract}
Este livro [O Antigo Regime e a Revolução] marcou uma época no próprio modo de conceber as origens da Revolução - e de representar sua história. Como bem observou Tocqueville: I. A Revolução ligava-se por todas as suas ruínas ao passado mais distante da nossa história; II. O seu caráter "religioso" devia-se às suas causas profundas; III. Por esta razão, não dependia de nenhum poder político abolir os seus efeitos. Por meio dessas duas obras [Democracia na América e $O$ Antigo Regime e a Revolução], ninguém fez mais do que Tocqueville para subtrair a história do julgamento arbitrário do historiador e preparar a ideia que sobre ela estamos formando hoje em dia, imprimindo-lhe todos os caracteres de ciência que lhe podem ser dados ${ }^{33}$.
\end{abstract}

No início do século $\mathrm{XX}$, foi a vez de outro eminente crítico literário, Émile Faguet, elogiar as qualidades exibidas por Tocqueville como historiador em sua obra de 1856: "bom historiador, bom observador, muito próximo de ser um grande escritor" 34 , ele "enxerga na história o necessário, o provável, o imprevisto e o acidental, materiais a partir dos quais construir uma filosofia da história é arriscado, uma aventura que ele sempre se recusou a seguir"35. Após destacar a adesão sincera do escritor "patrício liberal" à causa da democracia, Faguet encerrou sua análise sobre Tocqueville com o seguinte elogio:

Mais do que ninguém, ele teve a intuição do mundo moderno, daquilo que ele era e do que viria a ser, um homem cujas previsões foram as menos desmentidas

\footnotetext{
${ }^{32}$ Gustave Lanson, Histoire de la littérature française, p. 1003.

${ }^{33}$ Ferdinand Brunetière, Manuel de l'Histoire de la Littérature française, Paris, Ch. Delagrave, 1898, p. 441

${ }^{34}$ Emile Faguet, Politiques et moralistes du dix-neuvième siècle, T. 3, $6^{\mathrm{a}}$ edição, Paris, Société Française d'Imprimerie et de Librairie, 1903, p. 65.

${ }^{35}$ Ibídem, pp. 74-75.
} 
pelos fatos... Ofereceu algumas lições excelentes sobre o advento da democracia nos tempos modernos, e alguns bons conselhos sobre as precauções a serem tomadas ao longo desta mudança. É um professor de política muito exato, esclarecido, bem-informado e de visões profundas ${ }^{36}$.

Todavia, nem mesmo as leituras elogiosas daqueles eminentes críticos inverteram a tendência geral amplamente desfavorável à recepção de $O$ Antigo Regime e a Revolução e de seu autor na França.

Como bem demonstrou F. Mélonio num excelente estudo, nas décadas finais do século XIX e no início do XX, Tocqueville era visto como um impostor ou um hipócrita tanto pela nova (e extrema) direita, representada pelas figuras de Charles Maurras e Georges Sorel, como pela esquerda sindicalista revolucionária. E mesmo no interior do vasto campo do centro liberal, a mensagem de cunho antiestatal de Tocqueville, especialmente após a consolidação da Terceira República na virada do século, perdera seu apelo junto aos intelectuais e políticos cada vez mais integrados ao regime ${ }^{37}$.

À esquerda do espectro político, exceção feita à ilustre figura de Jaurè ${ }^{38}$, sindicalistas e socialistas não se esqueciam do alinhamento do patrício liberal com a repressão de Cavaignac aos amotinados parisienses de junho de 1848 .

No extremo oposto do espectro político, tanto Georges Sorel -primo de A. Sorel- como os reacionários integrantes da Ação Francesa, capitaneados por Charles Maurras, condenaram Tocqueville sem apelação, responsabilizando-o por ter espalhado na opinião pública francesa a falsa noção de que o avanço da democracia era um fenômeno inexorável e providencial. Amparados na repercussão negativa do envolvimento norte-americano em recentes guerras contra a Venezuela (1895) e a Espanha (1898), que eles encararam como uma guinada imperialista daquele país, Maurras e outros colaboradores daquele movimento acusaram Tocqueville de ter empreendido sua defesa da democracia com base num diagnóstico falso sobre a sociedade e a política norte-americanas. A partir de uma leitura enviesada e equivocada de Tocqueville, aqueles autores sustentavam que os Estados Unidos, longe de serem a generosa, harmoniosa e pacífica terra da democracia e da liberdade que serviria de exemplo para o velho mundo, eram, na verdade, um império beligerante sob o comando da aristocracia dos dólares e do ferro, em alusão à burguesia industrial que aqueles reacionários abominavam tanto ou mais do que os seus inimigos socialistas de esquerda ${ }^{39}$.

\footnotetext{
${ }^{36}$ Émile Faguet, Politiques et moralistes du dix-neuvième siècle, p. 114.

${ }^{37}$ Françoise Mélonio, Tocqueville and the French. Tradução inglesa de Beth G. Raps, London, University Press of Virginia, 1998, p. 182.

${ }^{38}$ Segundo consta, o autor da Histoire socialiste de la Révolution française (História socialista da Revolução Francesa, 1900-1903) tirou proveito da descrição tocquevilliana dos infortúnios sofridos pelos camponeses exposta no segundo capítulo do Livro II de O Antigo Regime.

${ }^{39}$ Françoise Mélonio, op. cit., p. 179-181. Infelizmente, não logramos ter acesso à recente obra de
} 
Nem a isolada tentativa de reabilitação de Tocqueville por um integrante do movimento -Antoine Rédier, através de sua volumosa biografia Comme disait M. de Tocqueville, de 1925- reverteu a condenação do nosso autor. Para aqueles nacionalistas e monarquistas de tendências positivistas, os impasses epistemológicos e políticos daquele aristocrata liberal crítico da monarquia absolutista e do Estado centralizado eram um reflexo da estupidez e da extravagância típicas dos homens do século XIX ${ }^{40}$.

Com apenas seis edições entre o início da Terceira República e a eclosão da Primeira Guerra, o quadro negativo à recepção de $O$ Antigo Regime $e$ a Revolução não se alterou no entreguerras, quando publicaram-se tão somente quatro edições do livro na França. Quanto aos escritos completos de Tocqueville, publicados inicialmente por seu amigo Gustave de Beaumont (em nove volumes) entre os anos 1864-1866, seria preciso esperar até a década de 1950, quando se completaria um século da morte do autor, para que viesse à tona uma reedição dos mesmos.

Diante da maré nacionalista que contagiou a geração de 1914, da crise de 1929 e dos esforços de guerra e de reconstrução no pós-Segunda Guerra, era de se esperar que a mensagem liberal e descentralizadora de Tocqueville não encontrasse um terreno muito fértil para prosperar, o que explica o quaseesquecimento em que caíram o autor e seu "estudo" de 1856 sobre a Revolução nos anos em questão, conforme estão de acordo todos os principais intérpretes do nosso autor.

Paradoxalmente, o principal responsável pelo resgate da obra histórica de Tocqueville, enfatizando sua relevância para a compreensão do fenômeno revolucionário francês, foi ninguém menos do que o consagrado acadêmico e historiador socialista Georges Lefebvre.

Em seu primeiro estudo dedicado a Tocqueville, uma introdução de 1952 para o segundo volume das Oeuvres (obras completas) recém-lançadas pela Gallimard, Lefebvre destacou as origens nobiliárquicas do autor de $O$ Antigo Regime e a Revolução, que a seu ver explicariam os sentimentos contraditórios do mesmo em relação à Revolução. Ademais, tal origem possibilitava compreender a pouca simpatia ou relevância atribuídas à burguesia e à propriedade móvel na obra, em oposição à ênfase reservada ao tratamento da nobreza e do campesinato, ambos vinculados à propriedade fundiária ${ }^{41}$.

Pierre Gouirand, Tocqueville et l'Action Française, Paris, Apopsix, 2013, que certamente poderia ter lançado mais luz sobre o assunto.

${ }^{40}$ Françoise Mélonio, op. cit., p. 181.

${ }^{41}$ Entretanto, importa destacar que Lefebvre esteve longe de tecer considerações unilaterais a partir das origens sociais de Tocqueville. Como fez questão de frisar, o patrício normando casou-se com "uma inglesa mais velha e sem ascendência nobre", mesmo sabendo que aquilo seria encarado pela família como uma espécie de mésalliance, e teceu eloquentes elogios aos homens de 1789 (em $O$ Antigo Regime e a Revolução), que permitiam considerá-lo "um homem de seu tempo". Georges Lefebvre, "Introduction" [in J.-P. Mayer, ed.: Oeuvres complètes de Alexis de Tocqueville. T. II, Paris, 
Após observar que Tocqueville não citou nenhuma fonte nem avançou um relato completo sobre os eventos revolucionários, o acadêmico fez questão de enaltecer a seriedade da pesquisa histórica presente em $O$ Antigo Regime, resultado de uma investigação erudita e criteriosa dos documentos, sem a qual, como ele, Lefebvre, gostava de repetir, "não há história" possível ${ }^{42}$. Dentre os méritos do empreendimento de Tocqueville para o avanço da disciplina como ciência, Lefebvre destacou a descoberta, em algumas aldeias visitadas por ele, de documentos inéditos e até então inexplorados relativos ao imposto fundiário que a Constituinte prescrevera, e a comparação dos dados obtidos com as escrituras fundiárias (os terriers) do século XIV. Apontou ainda a leitura dos cadernos de queixas de 1789 e a consulta das atas das vendas dos bens do clero e do Record Office britânico (a correspondência diplomática britânica dos primeiros anos da Revolução ${ }^{43}$.

Em seguida, Lefebvre pontuou as diferenças entre Tocqueville e seus antecessores, mormente Michelet -como mais tarde Furet também o faria-, mas sem atribuir o pioneirismo da comparação a Lefebvre. Segundo o acadêmico socialista, enquanto os predecessores do autor de $O$ Antigo Regime e a Revolução ativeram-se ao relato, cabendo à História da Revolução Francesa (1847-1853), de Michelet, o mérito de ter elevado a narrativa dos eventos revolucionários ao estatuto de uma obra de arte (tratava-se de um "afresco"), Tocqueville levara "a síntese para este nível superior, onde a desordem dos eventos se desvanece, os traços gerais da evolução se lançam à plena luz", produzindo uma interpretação que era "a mais bela que alguém poderia ter escrito sobre a Revolução.” Apesar de importantes figuras como Quinet e, logo em seguida, Taine, terem tentado "seguir os seus passos", eles não alcançaram "o mesmo domínio" e uma semelhante "serenidade" no tratamento da matéria histórica ${ }^{44}$.

Para o consagrado historiador francês que, entre os anos 1920 e 1930, inovara a historiografia com seus estudos sobre a Revolução, ao praticar uma história social que articulava as condições materiais objetivas com os quadros mentais das classes - especialmente do campesinato, despertando a atenção dos historiadores para os sentimentos e a mentalidade das classes subalternas (naquilo que ele definiu como l'histoire vue d'en bas) -, o que havia de particularmente digno de nota em $O$ Antigo Regime e a Revolução (bem como nas notas de leitura e esboços daquilo que deveria constituir o segundo volume prometido pelo autor, e que a Gallimard lançaria no ano seguinte mesmo em seu

\footnotetext{
Gallimard, 1952], p. XI-XIII.

${ }^{42}$ Ibídem, p. XVII. Um pouco antes, lemos que "Tocqueville jamais se limita às formulações abstratas: ele cita com o apoio dos fatos e dos textos. E ele não os escolhia ao acaso, devendo-os a pesquisas de fôlego; esse sociólogo se curvava às exigências da disciplina histórica”. p. XVI.

${ }^{43}$ Georges Lefebvre, Introduction, p. XVIII-XIX.

${ }^{44}$ Ibídem, p. XIX.
} 
formato inacabado) era a atenção dispensada à "influência social da economia" e ao "conflito entre as classes" 45 em sua história da Revolução:

\begin{abstract}
Entre as causas da Revolução, ele inscreve a prosperidade das décadas que a precederam: fortalecendo a burguesia, apressou-a; ele percebe a importância da crise industrial que atribui ao tratado de 1786; da carestia causada pela má colheita de 1788; do rigor do inverno em 1789: "Esse acidente da natureza foi um grande acontecimento político". ${ }^{46}$
\end{abstract}

Lefebvre também elogiou Tocqueville pela, segundo ele, correta e original compreensão de que a Revolução se iniciara em 1787 -através da ferrenha oposição nobiliárquica às sucessivas tentativas de reforma fiscal pelos ministros de Luís $\mathrm{XVI}^{47}$, mas isto não o impediu de tecer algumas algumas considerações críticas à obra. Indica o contraste entre o tratamento privilegiado que Tocqueville concedera à nobreza e aos camponeses e a pouca importância delegada à burguesia, classe que "liderou a Revolução e obteve dela o maior benefício", ignorando por completo a "análise das origens" de sua riqueza. ${ }^{48}$

Mas a principal crítica do acadêmico dizia respeito à ideia mestra do livro, cuja interpretação, segundo ele, ignorou ou não explicou de modo satisfatório seja a obra descentralizadora da Constituinte seja as causas da recaída dos revolucionários na centralização durante a Revolução. Lefebvre advertiu que, não obstante seu conteúdo libertário, a mensagem de $O$ Antigo Regime e a Revolução resvalava para o fatalismo, uma vez que atribuía demasiada ênfase no ressurgimento da centralização após 1789 sem, no entanto, refletir sobre as suas causas. E a principal causa negligenciada por Tocqueville, sem a qual a Revolução, a seu ver, corria o risco de não ser mais do que uma monstruosidade levada a cabo por "celerados" (como no retrato que Taine fizera dos jacobinos) era a guerra ${ }^{49}$. Que o "eminente sociólogo e historiador" tivesse deixado tal lacuna era "surpreendente", advertia Lefebvre, sobretudo por ele não se ter "dado conta de que a ditadura militar se explica parcialmente pela defesa da Revolução, e que ela permitiu a destruição do Antigo Regime na parte da Europa onde o Grande Exército triunfou". ${ }^{50}$ Isto explicaria o "lugar insignificante" -poderíamos dizer, ausência- de um tratamento sobre o Terror na obra, pois era "evidente que a orientação de seu pensamento o levou a passar da Assembleia Constituinte para Bonaparte... O episódio democrático do ano II repugnava-o" 51 .

\footnotetext{
${ }^{45}$ Ibídem, p. XXI e XXIII.

${ }^{46}$ Ibídem, p.XXII.

${ }^{47}$ Ibídem, p.XXVI.

${ }^{48}$ Ibídem, p.XXVIII.

${ }^{49}$ Ibídem, p.XXIX.

${ }^{50}$ Ibídem, p.XXX.

${ }^{51}$ Ibídem, p.XXIX-XXX.
}

Araucaria. Revista Iberoamericana de Filosofia, Politica, Humanidades y Relaciones Internacionales, año $21, \mathrm{n}^{\circ} 42$. Segundo semestre de 2019. Pp. 319-349. ISSN 1575-6823 e-ISSN 2340-2199 doi: 10.12795/araucaria.2019.i42.13 
Feitas as ressalvas, Lefebvre encerrou sua crítica num tom abertamente elogioso, salientando que, "por mais justas que tais reservas pareçam, impõese observar que elas não atenuam o respeito" e a "admiração" que a obra de Tocqueville inspira" ao "historiador" 52 .

Em 1955, o acadêmico dedicaria um segundo estudo a Tocqueville e seu livro de 1856. Publicado nos Annales Historiques de la Révolution française, o artigo novamente destacava a erudição e a originalidade da obra nos quadros da historiografia revolucionária.

No tocante à originalidade, Lefebvre comparou a abordagem de Tocqueville com as histórias de Mignet, Thiers e Michelet, observando que enquanto estes datavam o início da Revolução em 1789 e "reivindicavam a gloriosa responsabilidade" ora para o "Terceiro Estado, isto é, para a burguesia" (Thiers e Mignet), ora para o "Povo", ao "conjunto da Nação" (Michelet), "Tocqueville", na esteira de Chateaubriand, viu claramente que a nobreza", a partir de 1787, começou a revolução que "os plebeus" terminariam..$^{53}$

Em seguida, Lefebvre elogia o fato de Tocqueville integrar em sua história revolucionária não só as causas profundas mas também as circunstanciais, articulando de maneira "ímpar" os fatores políticos (e, no interior dos mesmos, a psicologia dos agentes) e econômicos. Pois, ao mesmo tempo em que "discerne as origens profundas" da Revolução - a decadência da aristocracia como resultado de um longo processo civilizatório, processo este caracterizado seja pela ação do absolutismo monárquico seja pelo avanço do "comércio", da "indústria", "das finanças que enriqueceram a burguesia" -, Tocqueville "tem pleno conhecimento de que as causas imediatas precipitam os acontecimentos: a crise econômica dos últimos anos do Antigo Regime, cuja responsabilidade", lemos no artigo, "ele atribuiu equivocadamente ao tratado comercial anglofrancês de 1786; a carestia provocada pela má-colheita de 1788 e a completa liberação do comércio de grãos; o rigoroso inverno de 1789." ${ }^{54}$

Consciente da complexidade dos fatores causais e de suas influências recíprocas, Tocqueville, sempre de acordo com Lefebvre, não apenas evitava a "tentação de explicar os acontecimentos apenas pela psicologia dos agentes", como dedicava um espaço privilegiado ao "impacto social da economia" e à "luta de classes" em sua história. Liberto do relato e "ultrapassando a narração", ele "merece ser louvado por ter implicitamente proclamado que sem erudição não se faz história", por ter exemplificado que, "para dominar os fatos, primeiramente é preciso estabelecê-los da maneira mais precisa possível". E conclui com a observação de que pelo fato de ter ultrapassado "a narração", plano ao qual se ativera a historiografia precedente, "O Antigo Regime $e$

\footnotetext{
${ }^{52}$ Ibídem, p.XXX.

${ }^{53}$ Georges Lefebvre, “À propos de Tocqueville”in Annales Historiques de la Révolution française, vol. XXVII (1955), p. 318

54 Ibídem, pp. 319-320.
}

Araucaria. Revista Iberoamericana de Filosofia, Política, Humanidades y Relaciones Internacionales, año $21, \mathrm{n}^{\circ} 42$ Segundo semestre de 2019. Pp. 319-349. ISSN 1575-6823 e-ISSN 2340-2199 doi: 10.12795/araucaria.2019.i42.13 
a Revolução foi, neste sentido, o mais belo livro que já se escreveu sobre o tema"s5.

Antes de prosseguirmos, importa destacar que os dois principais discípulos de Lefebvre no âmbito da historiografia da Revolução Francesa, os marxistas Albert Soboul e Eric Hobsbawm avançaram juízos absolutamente discrepantes em relação ao que o primeiro dissera acerca de Tocqueville. Assim, enquanto Soboul, no Prefácio de sua La Révolution Française (1984), comete o grave equívoco de descrever o autor de $O$ Antigo Regime e a Revolução como um dentre "os doutrinários mais conscientes da burguesia", Hobsbawm, em Ecos da Marselhesa (1990), afirma que "os escritos de Tocqueville sobre a Revolução foram mal lidos, como se fossem declarações de que ela não era necessária e afirmações a favor da continuidade histórica da evolução francesa" ${ }^{" 56}$.

Conforme vimos, não é preciso ter muita imaginação para concluir que Lefebvre desautorizaria as leituras de seus discípulos, na medida em que ele vinculava a ideia mestra da obra-a crítica liberal à centralização administrativa-, às origens sociais aristocráticas de seu autor, as quais permitiam compreender sua antipatia e pessimismo em relação à Revolução, expressa pelo conceito de continuidade ${ }^{57}$.

Também importa recordar que, paralelamente ao resgate de nosso autor por parte de Lefebvre no início da década de 1950, o nome e o pensamento de Tocqueville apareceram em importantes obras filosóficas daquele período, como As Origens do Totalitarismo (1951), de Hannah Arendt, e As Origens do Totalitarismo Democrático (1952), de Jacob L. Talmon.

Todavia, o papel de principal divulgador das ideias de Tocqueville para além do âmbito historiográfico coube inegavelmente ao filósofo e sociólogo

\footnotetext{
${ }^{55}$ Ibídem,, p. 321. Num estudo póstumo e mais amplo dedicado à historiografia, Lefebvre escreveu algo parecido sobre $O$ Antigo Regime e a Revolução, segundo ele "um livro magnífico, que não é uma história da Revolução, mas que, apesar disso, é o mais belo que já se escreveu sobre a Revolução, e que deveria servir de breviário aos historiadores da época para organizar o trabalho de pesquisas eruditas." Georges Lefebvre, Réflexions sur l'histoire, Paris, François Maspero, 1978, p. 230.

${ }^{56}$ Albert Soboul, La Révolution Française, Paris, Gallimard, 1984, p. 45; Eric Hobsbawm, Ecos da Marselhesa: dois séculos reveem a Revolução, São Paulo, Companhia das Letras, 1996, p. 45. Devo esta observação ao professor Modesto Florenzano.

${ }^{57}$ Conceito que levou o economista Albert O. Hirschman a classificar a obra tocquevilliana como um perfeito exemplar da "tese da futilidade". Cf. A. Hirschman, A retórica da intransigência: perversidade, futilidade, ameaça. Tradução de Tomás Rosa Bueno, São Paulo, Companhia das Letras, 1992, p. 48, onde se lê: "Com efeito, apenas recentemente a obra recebeu uma atenção especial por parte de um historiador francês importante, mais especificamente de Furet. A razão para essa estranha negligência não pode ser apenas por que, na França, Tocqueville foi durante muito tempo tido como conservador ou reacionário em um meio cujas simpatias estavam predominantemente com a Revolução e com a esquerda. A posição de Taine foi muito mais hostil à Revolução que a de Tocqueville, e no entanto seu livro Les origines de la France contemporaine foi levado muito mais a sério por Alphonse Aulard e outros praticantes do ofício. Talvez a adoção da tese da futilidade por Tocqueville tenha sido responsável por essa negligência: os historiadores dos períodos posteriores nunca o perdoaram inteiramente por ter levantado dúvidas acerca do caráter pivotal da Revolução Francesa - o fenômeno a cujo estudo, afinal de contas, eles estavam dedicando suas vidas".
} 
francês Raymond Aron, cujas principais obras -O ópio dos Intelectuais (1955), Ensaios sobre as liberdades (1965), As etapas do pensamento sociológico (1967) - exibiam a presença de Tocqueville tanto na letra como no espírito. Como bem observou o historiador Tony Judt a respeito deste importante vínculo intelectual:

\begin{abstract}
Em Tocqueville, Aron encontrou um espírito afim, um homem cuja compreensão das explicações sociais e políticas lhe dava uma plataforma a partir da qual ver mais fundo nas fontes históricas e contemporâneas dos problemas do seu tempo do que qualquer um de seus pares. Dos três teóricos sociais do século XIX que mais interessavam Aron, era Tocqueville quem tinha a visão que mais se assemelha às sociedades da Europa Ocidental na década de $60^{58}$.
\end{abstract}

Obcecado, desde os anos de estudante, "pela fragilidade dos sistemas políticos liberais e pela ameaça da anarquia e do despotismo" 59 , Aron encontrou em Tocqueville alguém que advertira sobre os riscos presentes no "impulso irresistível da democracia caso as instituições representativas fossem arrastadas pela impaciência das massas, caso o sentido de liberdade, aristocrático na origem, se apagasse" 60 .

De volta à História, vale destacar que na década seguinte, marcada pela memória de centenário do falecimento do autor, o clássico de Tocqueville receberia um papel de relevo nos estudos historiográficos de quatro importantes acadêmicos, na ordem: Marcel Reinhard ${ }^{61}$, amigo de Lefebvre e professor titular da prestigiosa cadeira de História da Revolução Francesa na Sorbonne, que redigiu um artigo especial sobre Tocqueville e sua obra de 1856 para a coletânea Tocqueville: Livre du Centenaire 1859-1959 (1960), reproduzido nos Annales historiques de la Révolution française; Jacob-Peter Mayer ${ }^{62}$, o editor alemão das obas completas de Tocqueville lançadas pela Gallimard no início da década de 1950 e autor, entre vários estudos dedicados a Tocqueville, de uma

58 Tony Judt, O peso da responsabilidade: Blum, Camus, Aron e o século XX francês, Rio de Janeiro, Objetiva, 2014. Locais do Kindle 2850-2853.

${ }^{59}$ Ibídem, Locais do Kindle 2895-2898.

${ }^{60}$ Raymond Aron, O Ópio dos Intelectuais (1955). Tradução de Jorge Bastos, São Paulo, Três Estrelas, 2016, p. 32.

${ }^{61}$ Marcel Reinhard, "Tocqueville, historien de la Révolution", in Annales historiques de la Révolution Française, no 161 (jul.-set. 1960), pp. 257-265.

${ }^{62}$ Jacob-Peter Mayer, "Matériaux pour une histoire de l'influence de L'Ancien Régime et la Révolution", [in J.-P. Mayer, Introduction à L'Ancien Régime et la Révolution, Paris, Gallimard, 1964]. Sublinhemos que antes de ter seu nome presente como editor das Obras Completas de Tocqueville pela editora Gallimard, Mayer já havia publicado um prestigioso estudo sobre o pensamento de Tocqueville (Alexis de Tocqueville, Paris, Gallimard, 1948), e o qual, enfocando na denúncia tocquevilleana à centralização estatal por seu caráter antecipatório dos regimes totalitários de massas, basicamente reproduzia o que ele já havia escrito num trabalho sobre Tocqueville de 1939, o ensaio Prophète de l'ère des masses. Une Étude sur Alexis de Tocqueville (não por acaso, redigido nos quadros da dominação nazista na Alemanha).

Araucaria. Revista Iberoamericana de Filosofía, Política, Humanidades y Relaciones Internacionales, año $21, \mathrm{n}^{\circ} 42$. Segundo semestre de 2019. Pp. 319-349. ISSN 1575-6823 e-ISSN 2340-2199 doi: 10.12795/araucaria.2019.i42.13 
breve mas luminosa introdução para uma nova edição da obra (de 1964), na qual destacava a influência de $O$ Antigo Regime e a Revolução no pensamento político europeu, de John Stuart Mill a Fustel de Coulanges, H. Taine, Albert Sorel, Vilfredo Pareto, B. Croce, etc; John McManners ${ }^{63}$, professor de Oxford especializado em história eclesiástica e que colaborou com um capítulo sobre a historiografia da Revolução Francesa para um dos volumes da importante coletânea da New Cambridge Modern History; Jacques Godechot ${ }^{64}$, historiador da Revolução Francesa que concluiu seu doutorado sob a orientação de Lefebvre e, dentre outras coisas, se notabilizara pelos estudos acerca da expansão revolucionária na Europa durante as guerras do Diretório e do Império napoleônico, da Contrarrevolução e, sobretudo, por haver formulado, na companhia de Robert Roswell Palmer, um professor norte-americano de Princeton e Yale especializado nas revoluções norte-americana e francesa (um dos tradutores de Lefebvre naquele país), o polêmico conceito de "Revolução Atlântica".

Em que pese a importância desses trabalhos, insistiremos no fato de que uma leitura atenta dos mesmos demonstrará que, para aquilo que aqui nos interessa, tais estudos pouco acrescentaram em relação ao que já escrevera Lefebvre, de modo que o papel de Tocqueville para a historiografia da Revolução Francesa fora mantido no alto relevo que lhe deixara o autor do Quatre-Vingt-Neuf (1939). De comum em todos eles, os elogios à seriedade da pesquisa empreendida pelo autor de $O$ Antigo Regime e a Revolução (que consultou os arquivos nacionais, departamentais e municipais, além das fontes primárias e secundárias, não excluindo a literatura da época em sua apreciação das mentalidades), refletida na obra pela complexa articulação entre as causas políticas (incluindo as mentalidades) e sócio-econômicas (como a original proposição de que a Revolução iniciara como uma revolta nobiliárquica).

Portanto, é possível dizer que, entre as décadas de 1950 e 1970, o nome de Tocqueville e sua obra foram constantemente resgatados no interior do campo historiográfico, e, a despeito da crescente onda revisionista iniciada por Alfred Cobban em 1955, também e sobretudo pelos autores vinculados ao espectro político progressista e de centro-esquerda ${ }^{65}$.

Prova-o o que escreveu a respeito de $O$ Antigo Regime e a Revolução a historiadora Alice Gérard, cujo luminoso livro dedicado à historiografia da Revolução Francesa, publicado em 1970, nos informa que:

\footnotetext{
${ }^{63}$ John McManners, "The Historiography of the French Revolution" [in A. Goodwin, The New Cambridge Modern History, vol. VIII: The American and the French Revolution 1763-1793, Cambridge University Press, 1965].

${ }^{64}$ Jacques Godechot, "As grandes correntes da historiografia da Revolução Francesa, de 1789 aos nossos dias" in Revista de História, n 80, vol. XXXIX (1969), pp. 423-470.

${ }^{65}$ Obviamente, durante o período em tela Tocqueville não foi ignorado pela direita, como a introdução de P. Gaxotte para uma nova edição de O Antigo Regime e a Revolução, publicada em 1960, o demonstra. Infelizmente, não conseguimos acessar esta edição.
} 
A obra de Tocqueville é ao mesmo tempo a mais original e a mais significativa da mentalidade liberal... Dentro dos limites da obra inacabada, Tocqueville renova a historiografia revolucionária por sua compreensão do problema das origens, distantes e próximas ${ }^{66}$.

E será a partir do início da década de 1970 que François Furet, já célebre por sua obra revisionista que redigida em coautoria com Denis Richet ( $\mathrm{La}$ Révolution Française, 1965), dedicará o primeiro de seus estudos sobre Tocqueville, mais especificamente o artigo de 1970 publicado nos Annales, "Tocqueville est-il un historien de la Révolution française?" ("Tocqueville é um historiador da Revolução Francesa?’).

Como o título já pressupõe, o tom do artigo é em larga medida crítico, de modo que quem o lesse antes da publicação de Penser la Révolution Française (1978) dificilmente suspeitaria que se trata do mesmo historiador que concedeu ao autor de $O$ Antigo Regime e a Revolução uma posição de destaque (ao lado de A. Cochin) em sua crítica revisionista à historiografia revolucionária.

Entre outros motivos, Furet censurou Tocqueville por ter sido "vago" no terreno da economia ("uma dimensão da vida dos homens que nunca o interessou") ${ }^{67}$ e haver superestimado a centralização administrativa, cujas etapas e progressos, segundo ele, receberam poucos detalhes ou explicações (nada sobre o papel das guerras; Luís XIV sequer era citado, etc). O livro também não informava nada sobre os offices, "fenômeno histórico central da constituição de uma burocracia monárquica, mas um dado ambíguo para sua tese, já que os cargos venais eram ao mesmo tempo um meio do poder central e um obstáculo ao mesmo"; quanto aos intendentes e demais funcionários administrativos do século XVIII, os mesmos achavam-se "profundamente divididos entre si, não apenas pelo jogo de ambições e clientelas, mas pelas opções político-ideológicas", longe portanto, da caracterização simplista de que eram "quase todos burgueses" $"$. E acrescenta:

Mais extraordinários ainda, em relação ao problema colocado, [são] certos silêncios de Tocqueville: quase nada... sobre os diferentes níveis intelectuais e ideológicos da população francesa. Há simplesmente, no topo, a cultura das Luzes e, no fundo, uma espécie de não-ser cultural, a não-civilização... Mesmo quando ele analisa, nos dois únicos capítulos concluídos do segundo volume do Antigo Regime, o estado de espírito dos franceses no final do Diretório, Tocqueville consegue passar em silêncio sobre o problema da paz e da guerra, que provavelmente domina, naquela época, toda a conjuntura interna francesa, e impedia, nas mentalidades e nos fatos, toda solução liberal da crise política ${ }^{69}$.

\footnotetext{
${ }^{66}$ Alice Gérard, A Revolução Francesa: Mitos e Interpretações. Tradução de Sérgio Joaquim de Almeida, São Paulo, Perspectiva, 1999, p. 60-61.

${ }^{67}$ François Furet, "Tocqueville est-il un historien de la Révolution française?" in Annales. Economies, sociétés, civilisations, № 2 (1970), p. 443.

${ }^{68}$ Ibídem, pp. 437-438.

${ }^{69}$ Ibídem, p. 450.
} 
Isto posto, o que importa destacar naquela releitura furetiana da obra de Tocqueville é a descoberta, pelo historiador revisionista, de dois elementos conceituais ainda não observados pelos intérpretes anteriores, respectivamente: I. uma inflexão conceitual entre as obras históricas de 1836 e 1856, com a causalidade sócio-econômica da historiografia liberal (que também seria, futuramente, a da historiografia universitária e de esquerda) cedendo espaço à causalidade política (numa acepção que incorpora e destaca a mentalidade e a ideologia dos agentes); II. uma espécie de bloqueio conceitual que explicaria seu tratamento banal sobre o Terror, bem como a omissão sobre a Assembleia Legislativa e a Convenção em suas notas de leitura para o segundo volume da obra, bloqueio este que o teria impedido (e não o seu falecimento no ano de 1859), em última análise, de elaborar "uma teoria da dinâmica revolucionária" e, portanto, de completar seu livro sobre o fenômeno revolucionário propriamente dito.

Como explicou Furet, no livro de 1856, "a sociedade civil aparece... menos como causa do que como consequência da sociedade política/moral: e talvez esta seja a originalidade intelectual fundamental de $O$ Antigo Regime e a Revolução, tanto em relação aos trabalhos anteriores de Tocqueville como em relação à sociologia política do século XIX de um modo geral"70. Ou seja, para o historiador da segunda geração dos Annales e, portanto, sob marcante influência da visão histórica braudeliana, o clássico de Tocqueville cumpria um duplo desígnio, ao mesmo tempo epistemológico e político: amparava o combate epistemológico/metodológico contra a historiografia universitária da Revolução, na medida em que não reproduzia o relato dos próprios revolucionários (vítimas eles próprios da ilusão revolucionária ${ }^{71}$ ), ao mesmo tempo que fornecia uma justificativa erudita para a tábula rasa dos fenômenos sociais e econômicos como fatores explicativos da Revolução, na exata contramão do que preconizara a historiografia acadêmica a partir de Lefebvre e seus sucessores (que, note-se, elogiaram Tocqueville justamente por, ao proceder através das múltiplas considerações causais, jamais prescindir da esfera sócio-econômica).

No contexto intelectual francês pós-maio de 1968, era natural que a obra tocquevilliana, com sua denúncia ao despotismo democrático, exercesse considerável apelo junto à opinião conservadora e liberal crítica ao totalitarismo

${ }^{70}$ F. Furet, op. cit., pp. 440-441. O artigo "Tocqueville e o problema da Revolução Francesa", publicado na Science et Conscience de la Societé no ano seguinte, e reproduzido em Pensando a Revolução Francesa, em 1978, praticamente desdobra e repete o que se encontra no artigo de 1970. O mesmo se aplica ao verbete "Tocqueville" que redigiu para o Dictionnaire critique de la Révolution Française, Paris, Flammarion, 1988, que organizou ao lado de Mona Ozouf.

${ }^{71}$ Visto que os "períodos revolucionários são por excelência os períodos obscuros da história, onde o véu da ideologia oculta ao máximo o sentido dos acontecimentos aos olhos dos atores do drama. É essa, sem dúvida, a contribuição fundamental de $O$ Antigo Regime e a Revolução. F. Furet, “Tocqueville est-il un historien de la Révolution française?", pp. 448-449. 
soviético e à ideologia revolucionária enquanto tal. Lembre-se que no mesmo ano em que Furet redigira seu artigo sobre Tocqueville, o dissidente político A. Soljenítsin seria congratulado com o prêmio Nobel de literatura.

E era justamente por seu valor epistemológico/metodológico que o excomunista e agora revisionista da Revolução resgatava Tocqueville, cuja história demonstrava que o segredo de 1789, Pensando a Revolução Francesa, não estava na dimensão econômica ou nas estruturas das classes, e sim no "estado de espírito dos franceses" ". A Revolução tampouco "recobre uma transformação política e social" -a qual, demonstrara Tocqueville, já tinha acontecido na reforma descentralizadora iniciada por Loménie de Brienne, em 1787, que se estendeu até o verão de 1789-, mas antes:

\footnotetext{
"traduz... duas modalidades específicas da ação histórica: o papel da violência e da ideologia (ou seja, da ilusão intelectual). Duas modalidades que, na realidade, são apenas uma. Pois a violência e o radicalismo político estão inscritos precisamente na ideologia escatológica do antes e do depois, do antigo e do novo, característica do projeto revolucionário" 73 .
}

Mas é no seu célebre livro de 1978, Penser la Révolution Française (Pensando a Revolução Francesa), mais especificamente no primeiro capítulo que traz como título "La Révolution Française est terminée", que Furet explicita suas razões para o resgate de Tocqueville. Segundo ele, a grande contribuição do aristocrata normando para a historiografia era de ordem metodológica, na medida em que o mesmo não compusera uma história da Revolução que se encontra "mais à direita" daquela escrita por Michelet e pelos historiadores universitários (os quais, a seu ver, celebram o fenômeno em vez de conceituá1o) ${ }^{74}$, mas uma história da Revolução que se fundamenta "en una crítica de la ideología revolucionaria y de lo que es, a su juicio, la ilusión que la Revolución Francesa se hizo de sí misma"75, na revelação de que "existe un abismo entre el balance de la Revolución Francesa y las intenciones de los revolucionarios"76.

Não por acaso, Furet encetou um ataque virulento e, poderíamos dizer, injusto e deselegante contra a figura de G. Lefebvre, ao mesmo tempo o historiador mais eminente da historiografia universitária (apesar de já falecido) e um leitor atento de Tocqueville - como admitira o próprio numa nota de página ${ }^{77}$. De acordo com o historiador revisionista, Lefebvre, diante

\footnotetext{
${ }^{72}$ F. Furet, op. cit., p. 445-446.

${ }^{73}$ Ibídem, p. 448.

${ }^{74}$ Como demonstrou C. Lefort e o próprio Furet concordaria (La Révolution en débat, Paris, Gallimard, 1999), este juízo não se aplicava a Michelet. Cf. Claude Lefort, "Penser la révolution dans la Révolution française", in Annales, Économies, Sociétés, Civilisations, 35ªno, n 2 (1980), pp. 339-340.

${ }^{75}$ F. Furet, Pensar la Revolución Francesa, p. 26.

${ }^{76}$ Ibídem, p. 28.

${ }^{77}$ Ibídem, p. 29.
}

Araucaria. Revista Iberoamericana de Filosofía, Política, Humanidades y Relaciones Internacionales, año $21, \mathrm{n}^{\circ} 42$. Segundo semestre de 2019. Pp. 319-349. ISSN 1575-6823 e-ISSN 2340-2199 doi: 10.12795/araucaria.2019.i42.13 
da constatação de que havia uma linha de continuidade na história rural francesa entre o Antigo Regime e a Revolução (qual seja, o parcelamento do solo em pequenas propriedades que, em última análise, explicava o atraso do desenvolvimento capitalista francês), não tirou as consequências lógicas daquela descoberta, isto é, não problematizou (como fizeram Tocqueville e ele próprio) o conceito (ou a "ilusão") da Revolução como advento ou uma ruptura radical entre o passado e o presente.

Georges Lefebvre había ya escrito en 1932: «El Antiguo Régimen había comprometido la historia agraria de Francia en el camino del capitalismo; la Revolución remató bruscamente la tarea que aquél había iniciado». Pero de esta comprobación que se asemeja en algo a la de Tocqueville, el historiador de tradición jacobina no extrae, como su antepasado de tradición legitimista, una crítica del concepto mismo de Revolución. No intenta comprender bajo qué condiciones es posible hacer coincidir la idea de un cambio radical y la de una continuidad objetiva... No es difícil demostrar que el más grande historiador universitario de la Revolución Francesa en el siglo XX, cuyo conocimiento del período ha sido el más rico y el más firme, sólo ha tenido, como visión sintética del inmenso acontecimiento al que consagró su vida, las convicciones de un militante del Cartel de las izquierdas o del Frente Popular ${ }^{78}$.

O fato é que o revisionismo de Furet, com toda sua capilaridade institucional e midiática angariada entre os anos 1970 e 1980, elevou Tocqueville, na feliz expressão de um historiador, à condição de "herói-teórico da triunfante vingança do liberalismo" no contexto da celebração do Bicentenário, a principal inspiração de toda a "galáxia furetiana", que incluiria nomes de peso na academia, como Marcel Gauchet e Pierre Manent.

Ligando os dois pontos do Atlântico, abordando a história pela longa duração, preocupado com todas as esferas da atividade social, Tocqueville atraiu tamanha deferência porque parecia fornecer as chaves para entender a natureza da democracia. É importante lembrar que, embora Tocqueville tenha florescido nos Estados Unidos no período imediato do pós-guerra..., ele não despertou uma atenção generalizada na França até os anos 1960, apesar dos valiosos esforços promocionais de Raymond Aron. Em suas fases iniciais, a republicação das obras de Tocqueville foi um evento quase confidencial na França ${ }^{79}$.

Em linhas parecidas, F. Mélonio, sublinhou como "a recente decomposição do comunismo, a partir de $1989 .$. realçou mais ainda o lustre de Tocqueville, conferindo-lhe uma vitória sobre Marx, que se proclama definitiva" ${ }^{\circ 0}$.

\footnotetext{
${ }^{78}$ F. Furet, op.cit., p. 20.

${ }^{79}$ Steven Laurence Kaplan, Farewell, Revolution: The Historians' Feud: France, 1789/1989, Ithaca, Cornell University Press, 1995, p. 117.

${ }^{80}$ François Melonio, Tocqueville and the French, p. 194.
} 
A propósito desta popularidade auferida por Tocqueville na virada do milênio, Aglaia I. Hartig e O. Bétourné reconheceram a importância de Furet, não sem observar que o último se apropriou daquilo que o interessava na obra Tocqueville, relegando ao esquecimento tudo o que não se coadunava com a sua nova interpretação da Revolução. Ao vincular seu estudo da Revolução à análise da ideologia revolucionária de um modo totalmente desconectado das relações sociais e das circunstâncias que permearam as tomadas de decisões pelos agentes (subsumindo todas as ações ao que Furet designou como "circuito semiológico"), o autor de Pensando a Revolução acabou, na visão dos autores, por distorcer a mensagem de Tocqueville, para quem a Revolução era, acima de tudo, uma questão simultaneamente social, política e ideológica ${ }^{81}$.

Com a aproximação das celebrações (ou, lamentações, se considerarmos a abordagem revisionista de Pierre Chaunu, que descrevia a Revolução como um "genocídio" do povo francês por uma horda de celerados) do Bicentenário de 1789, o autor de $O$ Antigo Regime e a Revolução seria objeto, entre incontáveis estudos, de uma excelente biografia -a mais erudita e, não obstante a simpatia de seu autor pelo biografado, a mais equilibrada já publicada sobre ele-, assinada por André Jardin ${ }^{82}$ (Alexis de Tocqueville 1805-1859, Paris, Hachette, 1984), e de verbetes especiais redigidos por François Furet e Philippe Raynaud para as concorrentes e prestigiosas coletâneas temáticas sobre a Revolução Francesa a serem lançadas em função das celebrações do Bicentenário, respectivamente o Dictionnaire Critique de la Révolution Française (Paris: Flammarion, 1988), organizado pelo próprio Furet em companhia de M. Ozouf, e o L'État de la France Pendant la Révolution (Paris: La Découverte, 1988), organizada pelo sucessor de Soboul na cátedra de História da Revolução Francesa na Sorbonne, Michel Vovelle.

E apesar de algumas leituras críticas, como a de René Pillorget num artigo de 1987 -o qual, não seria exagero dizer, atualiza as acusações de SainteBeuve ao autor de $O$ Antigo Regime e a Revolução, ao enfatizar a imprecisão na descrição tocquevilliana acerca da centralização administrativa do Antigo Regime; um reflexo, segundo ele, de seu pertencimento à classe aristocrática ("Tocqueville, com efeito, defende uma causa: aquela de seu grupo social, a da nobreza") e da falta de qualidade do autor como historiador ("a obra de Tocqueville logra uma abordagem muito maior da verdade sociológica e política de seu tempo do que da verdade histórica"83 -, Tocqueville e a sua obra

\footnotetext{
${ }^{81}$ Aglaia I. Hartig e Olivier Bétourné, Penser l'histoire de la Révolution: deux siècles de passion française, Paris, Éd. La Découverte, 1989, p. 30.

${ }^{82}$ Editor do volume das Oeuvres complètes de Alexis de Tocqueville que trariam os fragmentos e notas de leitura de L'ancien Régime et la Révolution: Fragments et notes inédites sur la Révolution, Paris, Gallimard, 1953, e autor de um estudo sobre o pensamento liberal francês, onde se encontra uma seção dedicada a Tocqueville - Histoire du Libéralisme Politique: de la crise de l'absolutisme à la constitution de 1875, Paris, Hachette, 1985.

${ }^{83}$ René Pillorget, "Vérité sociologique et vérité historique chez Tocqueville" in Gilbert Gadoffre e
} 
chegaram e saíram do Bicentenário consagrados acadêmica e editorialmente, tanto na França como do outro lado do Atlântico; tanto à esquerda como à direita do espectro político. Pois, como bem resumiu P. Raynaud em seu verbete para a obra coletiva organizada por M. Vovelle:

Para os historiadores de hoje, o interesse primeiro do livro de Tocqueville reside na apresentação da paradoxal continuidade entre a França do Antigo Regime e a nova sociedade resultante da Revolução. É por isso que, se a obra de Tocqueville é uma referência familiar do pensamento liberal (insere-se numa longa tradição de denúncia do caráter "absolutista" da tradição política francesa), também é igualmente admirada, de modo mais surpreendente, por certos historiadores "jacobinos" ou "marxistas" da Revolução (de Lefebvre a Soboul), na medida em que mostra o caráter ao mesmo tempo necessário e legítimo da Revolução, vista como um simples momento da evolução social ${ }^{84}$.

P. Chaunu, eds.: Certitutes et incertitudes de l'histoire, Paris, PUF, 1987, pp. 139 e 141.

${ }^{84}$ Philippe Raynaud, "Um Historiador da 'Longa Duração': Tocqueville" [in Michel Vovelle, ed.: França Revolucionária (1789-1799). Tradução de Denise Bottman, São Paulo, Brasiliense, 1989], p. 483. 


\section{Bibliografia:}

Aron, Raymond. As Etapas do Pensamento Sociológico. Traducción de Sérgio Bath São Paulo: Martins Fontes, 2008.

O Ópio dos Intelectuais (1955). Traducción de Jorge Bastos. São Paulo: Três Estrelas, 2016.

Bétourné, O. e Hartig, Aglaia. Penser l'histoire de la Révolution: deux siècles de passion française. Paris: Éd. La Découverte, 1989.

Boesche, Roger. "Why did Tocqueville think a succesfull Revolution was impossible?", in: Nolla, Eduardo (ed.). Liberty, Equality, Democracy. New York: New York University Press, 1992.

. Theories of Tyranny: From Plato to Arendt. Pennsylvania:

Pennsylvania Theories University Press, 1996.

. Tocqueville's Road Map. Methodology, Liberalism, Revolution and Despotism. New York: Rowman \& Littlefield, 2006.

Boffa, M. "La Rivoluzione e la Controrrivoluzione". In: F. Furet (ed.), L'eredità della Rivoluzione Francese. Roma: Laterza, 1989.

Brogan, Hugh. Alexis de Tocqueville. O Profeta da democracia. Traducción de Mauro Pinheiro. São Paulo: Record, 2012.

Brunetière, Ferdinand. Manuel de l'Histoire de la Littérature française. Paris: Ch. Delagrave, 1898.

Cochin, A. La Crise de l'histoire révolutionnaire. Taine et M. Aulard. Paris, H. Champion, 1909.

Compagnon, Antoine. Les antimodernes, de Joseph de Maistre à Roland Barthes. Paris: Gallimard, 2005.

Croce, Benedetto. Liberismo e liberalismo. Milano: Ricciardi, 1988.

Edelstein, Dan. The Terror of Natural Right: Republicanism, the Cult of Nature, and the French Revolution. Chicago: University of Chicago Press, 2009.

Elster, John. "Introduction", in: Tocqueville: The Ancien Régime and the French Revolution. New York: Cambridge University Press, 2011.

Erwin, Kevin M. "Le Mystique de la Tradition: Barbey Worships at the altar of Joseph de Maistre", in. C. Armenteros e R. Lebrun (eds.), Joseph de Maistre and his European Readers: From Friedrich von Gentz to Isaiah Berlin. Leiden: Brill, 2011, pp. 59-74.

Faguet, Émile. Politiques et moralistes du dix-neuvième siècle. Paris: Société Française d'Imprimerie et de Librairie, 1903, T. 3, 6ª edición.

Florenzano, Modesto. "Tocqueville diante da democracia e da Revolução". Revista do Instituto Histórico e Geográfico de São Paulo,vol. XCV, pp. 25-55, 1999.

Furet, François. Pensar la Revolución Francesa. Traducción de Arturo R. Firpo. Barcelona: Ediciones Petrel, 1980. 
. "Préface", in: Alexis de Tocqueville, De la Démocratie en Amérique. Paris: Flammarion, 1981, vol I.

Furet, François. "Tocqueville”, in: Furet, F. e Ozouf, Mona (eds.), Dicionário Crítico da Revolução Francesa. Traducción de Henrique de Araújo Mesquita. Rio de Janeiro: Nova Fronteira, 1989.

Furet, F. "Tocqueville est-il un historien de la Révolution française?", In: Annales. Economies, sociétés, civilisations, № 2, 1970, pp. 434-451.

. A Revolução em debate. Traducción de Regina Célia B. P. e Silva. Bauru-SP: EDUSC, 2001.

Gannet JR, Robert T. Tocqueville Unveiled: The Historian and his Sources for "The Old Regime and the Revolution". Chicago: University of Chicago Press, 2003.

Gengembre, Gerard. La Contre-Révolution ou l'histoire desesperante. Paris: Imago, 2001.

Gérard, Alice. A Revolução Francesa. Mitos e interpretações. Traducción de Sérgio Joaquim de Almeida. São Paulo: Ed. Perspectiva, 1999.

Godechot, Jacques. "As grandes correntes da historiografia da Revolução Francesa, de 1789 aos nossos dias." Revista de História, $\mathrm{n}^{\circ}$ 80, vol. XXXIX, 1969, pp. 423-470.

Gooch, G. P. History and Historians in the Nineteenth Century. London: Longmans, 1952.

Herr, Richard. Tocqueville and the Old Regime. Princeton: Princeton University Press, 1962.

Hirschman, Albert Otto. A retórica da intransigência: perversidade, futilidade, ameaça. Traducción de Tomás Rosa Bueno. São Paulo: Companhia das Letras, 1992.

Hobsbawm, Eric. Ecos da Marselhesa: dois séculos reveem a Revolução. Traducción de Maria C. Paoli. São Paulo: Companhia das Letras, 1996.

Hofman, Amon. "Opinion, Illusion, and the Illusion of Opinion: Barruel's Theory of Conspiracy". Eighteenth-century studies, vol. XXVII, $\mathrm{n}^{\circ} 1$, 1993, pp. 27-60.

Jardin, André. L'Ancien Régime et la Révolution: Fragments et notes inédites sur la Révolution. Paris: Gallimard, 1953. . Alexis de Tocqueville 1805-1859. Paris: Hachette, 1984. Histoire du Libéralisme Politique: de la crise de l'absolutisme à la constitution de 1875. Paris: Hachette, 1985.

Jasmin, Marcelo. "Historiografia e Liberdade em L'Ancien Régime et la Révolution", Revista Estudos Históricos, v. 9, n 17, 1996.

Jaume, Lucien. Le discours jacobin et la démocratie. Paris: Fayard, 1989. (ed.). Tocqueville and the aristocratic sources of Liberty. Princeton: Princeton Univerity Press, 2008. 
Paris: PUF, 2015.

Le Religieux et le Politique dans la Révolution Française.

Judt, Tony. O peso da responsabilidade: Blum, Camus, Aron e o século XX francês. Traducción de Otacílio Nunes. Rio de Janeiro: Objetiva, 2014.

Kaplan, Steven Laurence. Farewell, Revolution: The Historians' Feud: France, 1789/1989. Ithaca: Cornell University Press, 1995.

Lamberti, Jean-Claude. La notion d'individualisme chez Tocqueville. Paris: PUF, 1970.

Lanson, Gustave. Histoire de la littérature française. Paris: Hachette, 1895.

Lefebvre, Georges. "Introduction", in: J.-P. Mayer (ed.), Oeuvres complètes de Alexis de Tocqueville. T. II. Paris: Gallimard, 1952.

. "À propos de Tocqueville", in: Annales Historiques de la Révolution Française, 27, n 4, 1955, pp. 313-323.

Lefebvre, Georges. Réflexions sur l'histoire. Paris: François Maspero, 1978.

Lefort, Claude. C. Lefort, "Penser la révolution dans la Révolution française", Annales, Économies, Sociétés, Civilisations, $35^{\circ}$ ano, nº 2, 1980, pp. 334352.

Mayer, J-P. "Matériaux pour une histoire de l'influence de L'Ancien Régime et la Révolution", in: J.-P. Mayer, Introduction à L'Ancien Régime et la Révolution, Paris: Gallimard, 1964.

McManners, John. "The Historiography of the French Revolution", in: A. Goodwin (ed.), The New Cambridge Modern History, vol. VIII: The American and the French Revolution 1763-1793. Cambridge: Cambridge University Press, 1965.

Mellon, Stanley. The Political uses of History. Stanford: Stanford University Press, 1958.

Mélonio, Françoise. "Préface", in: Alexis de Tocqueville, L'Ancien Régime et la Révolution. Paris: Flammarion, 1988.

Mélonio, F. "Tocqueville aux origines de la démocratie française", in: Furet, F. e Ozouf, Mona (eds.), The French Revolution and the Creation of Modern Political Culture, vol 3, The Transformation of Political Culture, 17891848. New York: Pergamon Press, 1989.

Mélonio, F. Tocqueville and the French. London: University Press of Virginia, 1998.

Mélonio, Françoise e Diaz, José-Luis (eds.). Tocqueville et la Littérature. Paris: Presses Universitaires Paris-Sorbonne, 2005.

Mignet, François. Nouveaux Éloges Historiques. Paris: Didier et Cie, 1877.

Nolla, Eduardo (ed.). Liberty, Equality, Democracy. New York: New York University Press, 1992. 
Palmer, Robert Roswell. The Two Tocquevilles. Father and Son: Hervé and Alexis de Tocqueville on the Coming of the French Revolution. Princeton: Princeton University Press, 1987.

Pillorget, René. "Vérité sociologique et vérité historique chez Tocqueville", in: Gilbert Gadoffre e P. Chaunu (eds.), Certitutes et incertitudes de l'histoire (Paris: PUF, 1987) pp. 133-143.

Raynaud, Philippe. 'Um Historiador da 'Longa Duração': Tocqueville, in: Michel Vovelle (ed.), França Revolucionária (1789-1799). Traducción de Denise Bottman. São Paulo: Brasiliense, 1989.

Reinhard, M. “Tocqueville, historien de la Révolution', Annales historiques de la Révolution Française, no 161, 1960, pp. 257-265.

Rémusat, Charles de. "L'Ancien Régime et la Révolution, de M. de Tocqueville", Revue des Deux Mondes, 2érie, IV, 1856, pp. 652-670.

Riviale, Philippe. Tocqueville ou l'Intranquilité. Paris: L'Harmattan, 1997.

Sainte-Beuve, Charles Augustin. Causeries du Lundi, t. IV. Paris: Garnier Frères, 1852.

Causeries du Lundi, t. XV. Paris: Garnier Frères, 1857.

Portraits Littéraires, vol. II, Paris: Garnier Frères, 1862.

Soboul, Albert. La Révolution Française. Paris: Gallimard, 1984.

Taine, H. Les Origines de la France Contemporaine. Vol. 1. L'Ancien Régime. Paris: Hachette, 1909, $27^{\mathrm{a}}$ edición.

Vouga, Daniel. Baudelaire et Joseph de Maistre. Paris: J. Corti, 1957.

Welch, Cheryl B. (ed.). The Cambridge Companion to Tocqueville. New York: Cambridge University Press, 2006.

White, Hayden. Metahistory: The Historical Imagination in NineteenthCentury Europe. Baltimore: John Hopkins University Press, 1973.

Wolin, Sheldon. Tocqueville Between Two Words: The Making of a Political and a Theoretical Life. Princeton: Princeton University Press, 2003. 
